\title{
Chemical composition and bioactive properties of Cichorium spinosum L. in relation to nitrate/ammonium nitrogen ratio
}

\author{
Spyridon A Petropoulos, ${ }^{a^{*} \oplus \text { Ângela Fernandes, }}{ }^{\mathrm{b}}$ Ricardo C Calhelha, ${ }^{\mathrm{b}}$ \\ Francesco Di Gioia, ${ }^{\mathrm{C}}$ Panagiota Kolovou, ${ }^{\mathrm{a}}$ Lillian Barros ${ }^{\mathrm{b}} \odot$ and \\ Isabel C F R Ferreira ${ }^{b^{*}} \odot$
}

\begin{abstract}
BACKGROUND: Nitrogenous fertilizers may affect the yield and quality of leafy vegetables via the application rate and nitrogen form. In the present study, the effect of the nitrate:ammonium nitrogen ratio in the nutrient solution on the chemical composition and bioactive properties of Cichorium spinosum leaves was evaluated. For this purpose, $C$. spinosum plants were fertigated with nutrient solution containing different ratios of nitrate: ammonium nitrogen: (i) 100:0 $\mathrm{NO}_{3}-\mathrm{N}: \mathrm{NH}_{4}-\mathrm{N}$; (ii) 75:25 $\mathrm{NO}_{3}-\mathrm{N}: \mathrm{NH}_{4}-\mathrm{N}$; (iii) 50:50 NO 3 -N:NH $-\mathrm{N}$; (iv) 25:75 $\mathrm{NO}_{3}-\mathrm{N}: \mathrm{NH}_{4}-\mathrm{N}$; and (v) 0:100 $\mathrm{NO}_{3}-\mathrm{N}_{2} \mathrm{NH}_{4}-\mathrm{N}$ of total nitrogen; as well as (vi) $100 \%$ ureic nitrogen.

RESULTS: The only detected tocopherol isoforms were $\alpha$ - and $\delta$-tocopherol, which were positively affected by nitrate nitrogen (100:0 $\left.\mathrm{NO}_{3}-\mathrm{N}: \mathrm{NH}_{4}-\mathrm{N}\right)$. Similar results were observed for individual and total organic acids. The main detected sugars were fructose, glucose and sucrose, with a varied effect of nutrient solution composition on their content, whereas total sugar concentration was positively affected by a balanced or a slightly increased proportion of $\mathrm{NH}_{4}-\mathrm{N}\left(50: 50\right.$ and $\left.25: 75 \mathrm{NO}_{3}-\mathrm{N}: \mathrm{NH}_{4}-\mathrm{N}\right)$. The fatty acids profile was beneficially affected by the highest $\mathrm{NH}_{4}-\mathrm{N}$ ratio $\left(0: 100 \mathrm{NO}_{3}-\mathrm{N}^{\mathrm{N}} \mathrm{NH}_{4}-\mathrm{N}\right)$, whereas higher amounts of $\mathrm{NO}_{3}{ }^{-}$than $\mathrm{NH}_{4}{ }^{+}$nitrogen (75:25 $\mathrm{NO}_{3}-\mathrm{N}_{\mathbf{N}} \mathrm{NH}_{4}-\mathrm{N}$ ) resulted in a higher content of total phenolic compounds. Finally, no cytotoxic effects were observed against non-tumor (PLP2, HeLa) and tumor (HepG2, MCF-7, NCI-H460) cell lines for any of the studied nutrient solutions.
\end{abstract}

CONCLUSION: The modulation of $\mathrm{NO}_{3}-\mathrm{N} \mathrm{NH}_{4}-\mathrm{N}$ ratio in the nutrient solution supplied to $\mathrm{C}$. spinosum may enhance the content of desirable health-promoting compounds and reduce the content of antinutrients, thus increasing the overall quality of the final product without compromising yield.

๑) 2019 Society of Chemical Industry

Keywords: bioactive properties; Cichorium spinosum L.; cytotoxicity; nitrogen form; nitrate:ammonium nitrogen; nutrient solution composition; omega-3 fatty acids; phenolic compounds

\section{INTRODUCTION}

Cichorium spinosum $\mathrm{L}$. is a wild edible species that has received much recent attention as a potential alternative/complementary crop. Similar to other wild edible plants that are part of the traditional culinary heritage of the Mediterranean rural communities, ${ }^{1-3}$ C. spinosum is an ingredient of the so-called 'Mediterranean diet', which is associated with several beneficial health effects. ${ }^{4}$ There is a growing trend with respect to its commercial cultivation, which is usually based on cultivation practices applied on similar domesticated species (endives, chicory, lettuce) because of the scarce information available in the literature. Recently, our team has published information regarding the effect of salinity, ${ }^{5}$ nutrient solution composition ${ }^{6}$ and harvesting stage ${ }^{7}$ on the nutritional value and chemical composition of the plant edible leaves, whereas a chemical characterization of various $C$. spinosum ecotypes has been also reported. ${ }^{8}$

Nitrogenous fertilizers are pivotal for the achievement of high yields in vegetable crop production, although their use has raised concerns with regard to leafy vegetable production because excessive amounts of nitrogen may have implications for human health. ${ }^{9}$ Several studies have reported the importance of nitrogen form rather than the amount of total nitrogen, with significant effects not only on total yield, but also on marketable quality

\footnotetext{
* Correspondence to: SA Petropoulos, School of Agricultural Sciences, University of Thessaly, Fytokou Street, 38446, Nea Ionia, Magnissia, Greece. E-mail: spetropoulos@uth.gr or ICFR Ferreira, Centro de Investigação de Montanha (CIMO), Instituto Politécnico de Bragança, Campus de Santa Apolónia, 5300-253, Bragança, Portugal. E-mail: iferreira@ipb.pt

a University of Thessaly, Department of Agriculture, Crop Production and Rural Environment, Nea lonia, Magnissia, Greece

b Centro de Investigação de Montanha (CIMO), Instituto Politécnico de Bragança, Bragança, Portugal

c Department of Plant Science, Pennsylvania State University, University Park, PA, USA
} 
of the final vegetable products., ${ }^{6,10-12}$ Therefore, modulation of nutrient solution composition can be a cost-effective means for the improvement of vegetable quality either by decreasing antinutritional factors ${ }^{13}$ or by increasing beneficial compounds content. ${ }^{14-16}$ Phenolic compounds and omega- 3 fatty acids are of particular interest and an increase in their content in the final product is crucial for the achievement of high-added value products. ${ }^{12,17}$ Especially for phenolic compounds, it has been well-established via in vitro and in vivo studies that they possess several functional properties including antitumoral acitivities by inhibition of tumorigenesis and chemoprevention. ${ }^{18-20}$ Other important compounds with bioactive properties are tocopherols, which are present in plant tissues in various isoforms, and their content may be also regulated through the nutrient solution composition. ${ }^{6,21}$ However, despite the beneficial effects of the various bioactive compounds detected in wild edible plants, several toxicity symptoms have been reported; therefore, cytotoxicity studies against normal and cancer cells have to be carried out prior to suggesting the consumption of such species. ${ }^{22,23}$

In a previous study ${ }^{6}$, the effect of increasing ammonium nitrogen rates on plant growth and chemical composition of $C$. spinosum leaves was evaluated. In the present study, our aim was to further evaluate the effects of gradual nitrate:ammonium nitrogen ratios in nutrient solution on the chemical composition and bioactive properties of C. spinosum leaves. Accordingly, five fertilizer treatments with different ratios of nitrate: ammonium nitrogen were

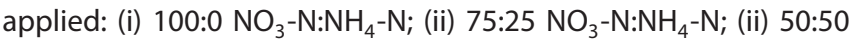
$\mathrm{NO}_{3}-\mathrm{N}: \mathrm{NH}_{4}-\mathrm{N}$; (iv) 25:75 $\mathrm{NO}_{3}-\mathrm{N}: \mathrm{NH}_{4}-\mathrm{N}$; and (v) 0:100 $\mathrm{NO}_{3}-\mathrm{N}: \mathrm{NH}_{4}-\mathrm{N}$ of total nitrogen; for comparison purposes, an extra treatment (vi) with $100 \%$ ureic nitrogen was also applied.

\section{MATERIALS AND METHODS}

\section{Plant material and experimental procedures}

The experiment was conducted at the experimental farm of the University of Thessaly, Greece. The plant material has been described previously. ${ }^{6,24}$ Briefly, seeds of C. spinosum L. (Asteraceae) were sown on 17 September 2016 in seed trays containing peat. When plants reached the stage of three or four true leaves (14/02/2017), young seedlings were transplanted in $2-L$ pots containing peat (Klassman-Deilmann KTS2) (1.0 L) and perlite $(1.0 \mathrm{~L}) .^{25}$ Fifteen pots, each containing one plant, were used for each fertilization treatment (90 pots in total). Fertilization of plants was carried out through the irrigation water with six fertilizer treatments $(1-6)$ containing the same amount of nitrogen $\left(200 \mathrm{mg} \mathrm{L}^{-1}\right)$. Fertilizer treatments differed in nitrogen source (ammonium, nitrate or ureic nitrogen) and their relative ratios: (i) 100:0 $\mathrm{NO}_{3}-\mathrm{N}: \mathrm{NH}_{4}-\mathrm{N}$; (ii) 75:25 $\mathrm{NO}_{3}-\mathrm{N}_{2} \mathrm{NH}_{4}-\mathrm{N}$; (iii) $50: 50$ $\mathrm{NO}_{3}-\mathrm{N}: \mathrm{NH}_{4}-\mathrm{N}$; (iv) 25:75 $\mathrm{NO}_{3}-\mathrm{N}: \mathrm{NH}_{4}-\mathrm{N}$; and (v) 0:100 $\mathrm{NO}_{3}-\mathrm{N}: \mathrm{NH}_{4}-\mathrm{N}$ of total nitrogen; as well as (vi) $100 \%$ ureic nitrogen. Nutrient solutions were prepared as described previously ${ }^{6}$ and as reported in Table 1 using the following fertilizers: (i) ammonium nitrate (34.5-0-0; $\mathrm{N}-\mathrm{P}_{2} \mathrm{O}_{5}-\mathrm{K}_{2} \mathrm{O}$ ); (ii) potassium nitrate (13.5-46.2-0; $\mathrm{N}-\mathrm{P}_{2} \mathrm{O}_{5}-\mathrm{K}_{2} \mathrm{O}$ ); (iii) magnesium nitrate (11-0-0; $\mathrm{N}-\mathrm{P}_{2} \mathrm{O}_{5}-\mathrm{K}_{2} \mathrm{O}+15$ $\mathrm{MgO}) ;$ (iv) ammonium sulphate (21-0-0; $\left.\mathrm{N}-\mathrm{P}_{2} \mathrm{O}_{5}-\mathrm{K}_{2} \mathrm{O}+24 \mathrm{SO}_{3}\right) ;(\mathrm{v})$ monopotassium phosphate (0-52-34; $\left.\mathrm{N}_{2} \mathrm{P}_{2} \mathrm{O}_{5}-\mathrm{K}_{2} \mathrm{O}\right)$; (vi) potassium sulphate (0-0-50; $\left.\mathrm{N}-\mathrm{P}_{2} \mathrm{O}_{5}-\mathrm{K}_{2} \mathrm{O}\right)$; (vii) monoammonium phosphate (12-61-0; $\mathrm{N}-\mathrm{P}_{2} \mathrm{O}_{5}-\mathrm{K}_{2} \mathrm{O}$ ); and (viii) $100 \%$ ureic nitrogen (46\% nitrogen in urea form).

Harvesting of plants was carried out once during the growing period (on 26 April 2017) and when the rosettes of leaves had reached marketable size. After harvest, samples of fresh leaves were put in freezing conditions, then lyophilized, ground with a mortar and pestle, placed in air-sealed food bags, and stored at deep freezing conditions $\left(-80^{\circ} \mathrm{C}\right)$ until further analyses.

\section{Chemical analyses \\ Tocopherols}

As described previously by Barros et al., ${ }^{26}$ hexane solutions of butyl-hydroxy-toluene $\left(10 \mathrm{mg} \mathrm{mL}^{-1} ; 100 \mu \mathrm{L}\right.$ ) and tocol (internal standard, $400 \mu \mathrm{L}$ at $50 \mu \mathrm{g} \mathrm{mL}^{-1}$ ), were added to $500 \mathrm{mg}$ of the sample prior to extraction. The combination was then homogenized with $4 \mathrm{~mL}$ of methanol by vortex mixing (1 $\mathrm{min}$ ), followed by $4 \mathrm{~mL}$ of hexane (vortex mixed for $1 \mathrm{~min}$ ). After sample homogenization, saturated $\mathrm{NaCl}$ aqueous solution $(2 \mathrm{~mL}$ ) was added, the mixture was combined (vortex for $1 \mathrm{~min}$ ), centrifuged ( $5 \mathrm{~min}$ at $4000 \times \mathrm{g}$ ) and the clear upper layer carefully transferred to a vial. Sample extraction with hexane was performed an additional two times. The combined extracts (clear layer) were taken to dryness under a nitrogen stream, dissolved in $2 \mathrm{~mL}$ of $n$-hexane, dehydrated with anhydrous sodium sulphate, filtered through a $0.2-\mu \mathrm{m}$ nylon filter (Whatman; GE Healthcare, Little Chalfont, UK), transferred into a dark injection vial and analyzed by high-performance liquid chromatography (HPLC) (Smartline system 1000; Knauer, Berlin, Germany) coupled to a fluorescence detector (FP-2020; Jasco, Easton, MD, USA).

\section{Soluble sugars}

For soluble sugars determination, a maceration with $1 \mathrm{~g}$ of dry sample spiked with melezitose (internal standard, $25 \mathrm{mg} \mathrm{mL}^{-1}$ ) and $40 \mathrm{~mL}$ of aqueous ethanol $(80 \%, \mathrm{v} / \mathrm{v})$ at $80{ }^{\circ} \mathrm{C}$ was performed. Afterwards, the sample was filtered and the solvent was evaporated. ${ }^{26}$ Identification and quantification of the individual sugars was performed via HPLC in conjunction with a refraction index detector and data were analyzed using Clarity, version 2.4 (DataApex, Prague, The Czech Republic). The results were expressed as $\mathrm{g} \mathrm{kg}^{-1}$ dry weight $(\mathrm{dw})$.

\section{Organic acids}

The samples were extracted by macerating $1 \mathrm{~g}$ of the sample and $25 \mathrm{~mL}$ of metaphosphoric acid (4.5\%) during $20 \mathrm{~min}$ at room temperature. After sample filtration, the samples were analyzed by ultra-fast LC coupled to a photodiode array detector using $215 \mathrm{~nm}$ and $245 \mathrm{~nm}$ (for ascorbic acid) as preference wavelengths (UFLC-PDA; Shimadzu Coperation, Kyoto, Japan), as described previously by Barros et al. ${ }^{26}$ The results were expressed as $\mathrm{g} \mathrm{kg}^{-1} \mathrm{dw}$.

\section{Fatty acids}

As described previously by Barros et al., ${ }^{26}$ fatty acid content was investigated after trans-esterification of the lipid fraction obtained through Soxhlet extraction. The samples were analyzed by gas-LC with flame ionization detection/capillary column and the results were recorded and processed using CSW, version 1.7 (DataApex) and expressed as a relative percentage for each fatty acid.

\section{Phenolic compounds characterization}

The hydroethanolic extract was obtained by maceration, using aqueous ethanolic solution $\left(80 \%, \mathrm{v} / \mathrm{v} ; 30 \mathrm{~g} \mathrm{~mL}^{-1}\right)$ at $25{ }^{\circ} \mathrm{C}$ for 60 min. After filtration (Whatman no. 4 filter), the sample was re-extracted once more using the same conditions. Afterwards, the solvent was evaporated at $40{ }^{\circ} \mathrm{C}$, under reduced pressure, in a rotary evaporator (model R-210; Büchi, Flawil, 
Table 1. Macronutrient concentrations $\left(\mathrm{mg} \mathrm{L}^{-1}\right)$ of the nutrient solution for each treatment

\begin{tabular}{lcccccccccc}
$\mathrm{NO}^{-}: \mathrm{NH}^{+}$ & Total nitrogen & $\mathrm{NO}_{3}{ }^{-}$ & $\mathrm{NH}_{4}^{+}$ & Urea & $\mathrm{K}$ & $\mathrm{P}$ & $\mathrm{Ca}$ & $\mathrm{Mg}$ & $\mathrm{S}$ \\
\hline $100: 0$ & 200 & 200 & 0 & 0 & 200 & 200 & 0 & 178.3 \\
$75: 25$ & 200 & 150 & 50 & 0 & 200 & 200 & 0 & 136.3 & 0 \\
$50: 50$ & 200 & 100 & 100 & 0 & 200 & 200 & 0 & 0 & 0 \\
$25: 75$ & 200 & 50 & 150 & 0 & 200 & 200 & 0 & 0 & 136.4 \\
$0: 100$ & 200 & 0 & 200 & 0 & 200 & 200 & 0 & 0 \\
Urea & 200 & 0 & 0 & 200 & 200 & 200 & 0 & 0 \\
\hline
\end{tabular}

Switzerland) and the residual aqueous extract was freeze dried (FreeZone 4.5 model 7750031 ; Labconco, Kansas City, MO, USA).

The dry extracts were re-suspended at a concentration of $10 \mathrm{mg} \mathrm{mL}^{-1}$ using aqueous ethanol $(50 \%, \mathrm{v} / \mathrm{v})$ and filtered $(0.2 \mu \mathrm{m}$ disposable LC filter disk, $30 \mathrm{~mm}$, nylon). Afterwards, the phenolic profile of C. spinosum leaves was determined by LC with a diode-array detector (wavelengths of 280,330 and $370 \mathrm{~nm}$ ) coupled with electrospray ionization mass spectrometry operating in negative mode (Dionex Ultimate 3000 UPLC and Linear lon Trap LTQ XL; Thermo Scientific, San Jose, CA, USA), as described previously. ${ }^{27}$ The phenolic compounds were identified according to their chromatographic characteristics by comparison with those obtained using standard compounds and also with the literature. Calibration curves of appropriate standards were obtained in the range $200-5 \mu \mathrm{g} \mathrm{mL}^{-1}$ for the quantitative analysis. The results were expressed as $\mathrm{g} \mathrm{kg}^{-1}$ extract.

\section{Cytotoxicity}

The extracts descrbed above were re-dissolved in water at a concentration of $8 \mathrm{mg} \mathrm{mL}^{-1}$ and further diluted in the range from 400 to $6.25 \mu \mathrm{g} \mathrm{mL}^{-1}$. The cytotoxic properties were evaluated using four human tumor cell lines: MCF-7 (breast adenocarcinoma); $\mathrm{NCl}-\mathrm{H} 460$ (non-small cell lung cancer); HeLa (cervical carcinoma); and HepG2 (hepatocellular carcinoma). A non-tumor cell line (PLP2) was evaluated using a procedure described previously by Abreu et al. ${ }^{28} \mathrm{~A}$ sulforhodamine $\mathrm{B}$ assay was carried out in accordance with the methods described by Barros et al., ${ }^{21}$ with ellipticine being used as a positive control. The results were expressed as $\mathrm{Gl}_{50}$ values (i.e. the concentration that inhibited $50 \%$ of cell proliferation).

\section{Statistical analysis}

Plant growth measurements were recorded on 15 plants per fertilizer treatment $(n=15)$. For chemical analyses and for each fertilizer treatment, three samples of leaves $(n=3)$ were analyzed. All chemical composition assays were carried out in triplicate. Data were analyzed via one-way analysis of variance and, when significant differences were observed, a comparison of means was performed using Tukey's honestly significant difference test $(P=0.05)$. SPSS, version 21 (IBM Corp., Armonk, NY, USA) was used for the data analyses.

For a visual representation of the results, data on yield, dry matter (DM) content and all of the nutritional parameters examined were subject to principal component analysis (PCA) using PAST3. ${ }^{29}$ Before carrying out the PCA, means were standardized $[(x-$ mean $) / S D)$. The data matrix subject to PCA was constituted by 18 samples ( 6 treatments $\times 3$ replicates) for each of the 36 variables examined.

\section{RESULTS AND DISCUSSION}

Previous studies investigating the impact of nitrogen form on the yield and quality of $C$. spinosum revealed a relatively low response to $\mathrm{NH}_{4}-\mathrm{N}$ in terms of fresh and dry biomass production. ${ }^{6,30} \mathrm{Nev}-$ ertheless, in both studies, the highest proportion of $\mathrm{NH}_{4}-\mathrm{N}$ tested was approximately $50 \%$ of the total $\mathrm{N}$ and a different response was observed based on the crop growth stage, with higher tolerance to $\mathrm{NH}_{4}-\mathrm{N}$ in the first versus the second growth period. ${ }^{6}$ In the present study, the $\mathrm{NO}_{3}-\mathrm{N}: \mathrm{NH}_{4}-\mathrm{N}$ ratio tested covered the full range of variation from $100 \% \mathrm{NO}_{3}-\mathrm{N}$ to $100 \% \mathrm{NH}_{4}-\mathrm{N}$, including 75:25, 50:50 and $25: 75 \mathrm{NO}_{3}-\mathrm{N}: \mathrm{NH}_{4}-\mathrm{N}$ ratios, as well as $100 \%$ ureic nitrogen as a control treatment. As previously reported by Kolovou et al., ${ }^{24}$ in the present study, the form of $\mathrm{N}$ applied had a significant impact on C. spinosum plant growth. Total number of leaves and total fresh weight were positively influenced by a higher proportion of $\mathrm{NO}_{3}-\mathrm{N}$, with the 100:0 and 75:25 $\mathrm{NO}_{3}-\mathrm{N}: \mathrm{NH}_{4}-\mathrm{N}$ ratios providing the highest plant fresh weight ( $45.8 \mathrm{~g}$ ) and number of leaves (43) per plant, respectively. However, as observed previously in a similar study by Petropoulos et al., ${ }^{6}$ also in this case, a positive response to a higher proportion of $\mathrm{NH}_{4}-\mathrm{N}$ was observed at the first and second harvest, whereas a negative effect on plant growth was observed at the third harvest. The lowest plant fresh biomass and number of leaves at all stages were produced by plants nourished with urea, which was noxious for $\mathrm{C}$. spinosum plants. ${ }^{24} \mathrm{The}_{\mathrm{NO}}-\mathrm{N}: \mathrm{NH}_{4}-\mathrm{N}$ ratio of the nutrient solution influenced also the DM content of C. spinosum leaves, causing an increase in DM with an increasing proportion of $\mathrm{NH}_{4}-\mathrm{N}$ over the total $\mathrm{N}$ up to the $25: 75 \mathrm{NO}_{3}-\mathrm{N}: \mathrm{NH}_{4}: \mathrm{N}$ ratio. ${ }^{24}$ These results suggest that the form of $\mathrm{N}$ may affect not only the dry biomass accumulation of $C$. spinosum, but also its water content and thus the fresh biomass. Despite producing the lowest dry biomass, having the highest water content, plants fertilized exclusively with $\mathrm{NO}_{3}-\mathrm{N}$ achieved the highest fresh yield. ${ }^{24}$ Similar to other leafy vegetables, the higher fresh yield of plants nourished with $\mathrm{NO}_{3}-\mathrm{N}$ may be the result of a higher accumulation of $\mathrm{NO}_{3}{ }^{-}$in the leaf tissues. Because of its osmotic effect, the accumulation of $\mathrm{NO}_{3}{ }^{-}$in plant tissues enhances the plant water uptake; indeed, an inverse relationship has been observed between the accumulation of $\mathrm{NO}_{3}{ }^{-}$and the DM content of leafy vegetables. ${ }^{31,32}$ Besides the effect on plant growth, the form of $\mathrm{N}$ supplied also had an impact on the nutritional profile of $C$. spinosum plants, influencing the content of all the metabolites analyzed in the present study.

\section{Effect of the $\mathrm{NO}_{3}-\mathrm{N}: \mathrm{NH}_{4}-\mathrm{N}$ ratio on sugars and organic acids}

The $C$. spinosum leaf sugar concentration was positively influenced by a balanced or a slightly increased proportion of $\mathrm{NH}_{4}-\mathrm{N}$ in the nutrient solution (Table 2). Compared with the $100 \% \mathrm{NO}_{3}-\mathrm{N}$ nutrient solution, increasing $\mathrm{NH}_{4}-\mathrm{N}$ up to $50 \%$ and $75 \%$ of the total- $\mathrm{N}$ determined an increase of $25.8 \%$ and $28.8 \%$ of the total sugar content, respectively. Such results were consistent with the 
Table 2. Composition in sugar $\left(\mathrm{g} \mathrm{kg}^{-1} \mathrm{dw}\right.$ ) of Cichorium spinosum leaves in relation to nutrient solution (NS) composition (mean $\pm \mathrm{SD}$ )

\begin{tabular}{|lcccc} 
& Glucose & Sucrose & $\begin{array}{c}\text { Total } \\
\text { sugars }\end{array}$ \\
\hline $100: 0$ & $15.1 \pm 0.3 \mathrm{~b}$ & $19.9 \pm 0.4 \mathrm{~d}$ & $24 \pm 1 \mathrm{~d}$ & $59 \pm 1 \mathrm{c}$ \\
$75: 25$ & $16.4 \pm 0.5 \mathrm{a}$ & $26 \pm 1 \mathrm{~b}$ & $26.9 \pm 0.3 \mathrm{c}$ & $69 \pm 1 \mathrm{~b}$ \\
$50: 50$ & $14.4 \pm 0.6 \mathrm{bc}$ & $24.9 \pm 0.8 \mathrm{~b}$ & $34.8 \pm 0.1 \mathrm{a}$ & $74.2 \pm 0.1 \mathrm{a}$ \\
$25: 75$ & $16.9 \pm 0.7 \mathrm{a}$ & $27.9 \pm 0.3 \mathrm{a}$ & $31.5 \pm 0.9 \mathrm{~b}$ & $76 \pm 2 \mathrm{a}$ \\
$0: 100$ & $14.7 \pm 0.5 \mathrm{bc}$ & $21 \pm 1 \mathrm{c}$ & $31 \pm 2 \mathrm{~b}$ & $67 \pm 4 \mathrm{~b}$ \\
Urea & $14.1 \pm 0.8 \mathrm{c}$ & $21 \pm 1 \mathrm{c}$ & $34.6 \pm 0.3 \mathrm{a}$ & $69 \pm 2 \mathrm{~b}$ \\
\hline
\end{tabular}

In each column, different lowercase letters indicate significant differences between samples according to Tukey's test $(P=0.05)$.

observation of Flore et al. $^{33}$ and could be the result of a higher energy efficiency of plants nourished with moderately higher proportions of $\mathrm{NH}_{4}-\mathrm{N}$. Sucrose represented the prevalent sugar (on average 44\%), followed by glucose (on average 34\%) and fructose (on average 22\%). The highest concentration of sucrose was observed in plants grown with a 50:50 $\mathrm{NO}_{3}-\mathrm{N} \mathrm{NH}_{4}-\mathrm{N}$ ratio or with urea, mostly at the expense of fructose, which showed the lowest concentration in the same plants. The highest and lowest concentrations of glucose were observed in plants grown with 75:25 and 100:0 $\mathrm{NO}_{3}-\mathrm{N}: \mathrm{NH}_{4}-\mathrm{N}$ ratios, respectively. Plants grown with 75:25 and 25:75 $\mathrm{NO}_{3}-\mathrm{N}: \mathrm{NH}_{4}-\mathrm{N}$ ratios had the highest concentration of fructose. Examining the sugar profile, no positive or negative relationships were observed between the concentration of the two monosaccharides and the disaccharide sucrose. Overall, total sugar concentrations were similar or within the lower range of values observed by Petropoulos et al. ${ }^{8}$ and Petropoulos et al..$^{6}$ for $C$. spinosum under similar growing conditions.

On the other hand, the concentration of total organic acids was highest in plants of $C$. spinosum grown with the highest proportion of $\mathrm{NO}_{3}-\mathrm{N}$ (Table 3). In accordance with the observation of Petropoulos et al., ${ }^{6}$ oxalic and quinic acid were the main organic acids detected, followed by malic and citric acid, along with traces of fumaric acid. The concentration of all the organic acids detected, including oxalic, quinic, malic and citric acid, was higher in the leaves of plants fertigated with $100 \% \mathrm{NO}_{3}-\mathrm{N}$ nutrient solution compared to all of the other plants fertilized with different $\mathrm{NO}_{3}-\mathrm{N}$ to $\mathrm{NH}_{4}-\mathrm{N}$ ratios, except for those grown with 25:75 $\mathrm{NO}_{3}-\mathrm{N}: \mathrm{NH}_{4}-\mathrm{N}$ ratio, which showed an equivalent concentration of oxalic acid. The lowest value of total organic acids were observed in plants fertigated with a $25: 75 \mathrm{NO}_{3}-\mathrm{N}: \mathrm{NH}_{4}-\mathrm{N}$ ratio, followed by those nourished with $100 \%$ ureic nitrogen, and the $50: 50 \mathrm{NO}_{3}-\mathrm{N} \mathrm{NH}_{4}-\mathrm{N}$ ratio. Such results are consistent with the findings of previous studies in which a reduction of organic acids was observed, especially of oxalic acid, with an increasing proportion of $\mathrm{NH}_{4}-\mathrm{N}$ versus $\mathrm{NO}_{3}-\mathrm{N}$ in the nutrient solution in the case of purslane, ${ }^{14}$ spinach $^{34}$ and C. spinosum. ${ }^{6}$ The higher accumulation of organic acids observed in the leaf tissues with an increasing proportion of $\mathrm{NO}_{3}-\mathrm{N}$ may be explained by the need of the plant to counterbalance the increase in $\mathrm{pH}$ associated with the uptake of $\mathrm{NO}_{3}-\mathrm{N} .{ }^{35}$ From a nutritional standpoint, a lower oxalic acid concentration is highly desirable in leafy vegetables with respect to avoiding the issues associated with the formation of oxalates. Oxalates, the salts formed between oxalic acid and Ca or other minerals, can limit the assimilation of essential elements ( $\mathrm{Fe}, \mathrm{Ca}, \mathrm{Mg}$ ) and cause the formation of insoluble crystals and subsequently stones in the kidneys or in the urinary tract. ${ }^{36}$ From this perspective, as proposed for other vegetables, an increase in the proportion of $\mathrm{NH}_{4}-\mathrm{N}$ in the nutrient solution may enhance the nutritional properties of $C$. spinosum by reducing the concentration of oxalic acid and limiting the potential formation of oxalates.

As for other food products, the profile of sugars and organic acids is a strong determinant of the sensory properties of leafy vegetables. The ratio of total sugar to total organic acids may be used as an indicator of the sensory properties of leafy greens. Examining the relationship between the $\mathrm{NO}_{3}-\mathrm{N}: \mathrm{NH}_{4}-\mathrm{N}$ ratio of the nutrient solution and the ratio of total sugar to total organic acids, large variations were observed, with values ranging from 0.29 in plants fertigated exclusively with $\mathrm{NO}_{3}-\mathrm{N}$ up to 0.56 in those fertigated with a 50:50 $\mathrm{NO}_{3}-\mathrm{N} \mathrm{NH}_{4}-\mathrm{N}$ ratio (Tables 2 and 3). In this perspective, future studies are warranted to investigate the potential of enhancing the flavor and sensory properties of leafy vegetables by modulating the $\mathrm{NO}_{3}-\mathrm{N}: \mathrm{NH}_{4}-\mathrm{N}$ ratio of the fertigating solution.

\section{Effect of the $\mathrm{NO}_{3}-\mathrm{N}: \mathrm{NH}_{4}-\mathrm{N}$ on tocopherols}

Cichorium spinosum plants fertigated with 100:0 $\mathrm{NO}_{3}-\mathrm{N}: \mathrm{NH}_{4}-\mathrm{N}$ ratio had the highest content of both $\alpha$ - and $\delta$-tocopherols, resulting in the highest content of total tocopherols for the same treatment (Table 4). Plants receiving nutrient solution with a $\mathrm{NO}_{3}-\mathrm{N}: \mathrm{NH}_{4}-\mathrm{N}$ ratio of 75:25 and urea as the sole source of nitrogen had the lowest $\alpha$ - and $\delta$-tocopherols, respectively, resulting in a $36.2 \%$ decrease on average of total tocopherols content compared to plants grown exclusively with $\mathrm{NO}_{3}-\mathrm{N}$. These results are partially in contrast with a previous study reorting an increase in $\alpha$-tocopherols with a $75: 25 \mathrm{NO}_{3}-\mathrm{N}: \mathrm{NH}_{4}-\mathrm{N}$ ratio versus $100 \% \mathrm{NO}_{3}-\mathrm{N}$, in two out of three genotypes of Portulaca oleracea. ${ }^{21}$ Intermediate total tocopherols concentrations were observed when $50 \%$, $75 \%$ or $100 \%$ of total nitrogen was applied with the form of $\mathrm{NO}_{3}-\mathrm{N}$. Overall, when expressed on a fresh weight basis, the total tocopherol concentration values measured were similar to those reported by Petropoulos et al. ${ }^{6}$ for first and second harvest of $C$. spinosum grown under similar conditions, as well as beiong similar to the values of total tocopherols reported for the wild ecotypes collected in situ and analyzed by Petropoulos et al. ${ }^{8}$

\section{Effect of the $\mathrm{NO}_{3}-\mathrm{N}: \mathrm{NH}_{4}-\mathrm{N}$ on the fatty acids profile}

Twenty-four different fatty acids including saturated fatty acids (SFA) (12.9\%), monounsaturated fatty acids (MUFA) (2.6\%) and polyunsaturated fatty acids (PUFA) (84.5\%) were detected by gas chromatography and a significant impact of the nutrient solution $\mathrm{NO}_{3}-\mathrm{N}: \mathrm{NH}_{4}-\mathrm{N}$ ratio was observed on the fatty acids profile of $C$. spinosum leaves (Table 5). Palmitic acid (C16:0) and palmitoleic acid (C16:1) constituted, on average, $74.8 \%$ and $75 \%$ of the SFA and MUFA, respectively; oleic acid (C18:1n9c) was the second most abundant (22.7\% on average) MUFA, whereas $\alpha$-linolenic acid (C18:3n3) constituted the primary (80.8\%) PUFA and fatty acid in general, followed by linoleic acid (C18:2n6c), which represented $18.8 \%$ of the PUFA. Overall, the observed fatty acid composition was similar to the fatty acid profile reported for different ecotypes of C. spinosum ${ }^{8}$ and C. spinosum harvested at different times. ${ }^{37}$ Although a lower omega-6/omega-3 fatty acids ratio was observed in the present study compared to that reported by Petropoulos et al. ${ }^{8}$ mainly as a consequence of a lower content of linoleic acid (C18:2n6c), for all the tested treatments, the ratio values were lower than 4.0, which, according to Guil et al., ${ }^{38}$ indicates a high nutritional value. When examining the effect of the $\mathrm{NO}_{3}-\mathrm{N}: \mathrm{NH}_{4}-\mathrm{N}$ ratio of the nutrient solution on the fatty acids composition, it was observed that an equal proportion of $\mathrm{NO}_{3}-\mathrm{N}$ and 
Table 3. Composition in organic acids $\left(\mathrm{g} \mathrm{kg}^{-1} \mathrm{dw}\right.$ ) of Cichorium spinosum leaves in relation to nutrient solution (NS) composition (mean \pm SD)

\begin{tabular}{lcccccc}
$\mathrm{NO}_{3}{ }^{-}: \mathrm{NH}_{4}{ }^{+}$ & Oxalic acid & Quinic acid & Malic acid & Citric acid & Fumaric acid & Total organic acids \\
\hline $100: 0$ & $56.1 \pm 0.1 \mathrm{a}$ & $98.4 \pm 0.7 \mathrm{a}$ & $31.8 \pm 0.1 \mathrm{a}$ & $18.6 \pm 0.1 \mathrm{a}$ & $\operatorname{tr}$ & $205.0 \pm 0.8 \mathrm{a}$ \\
$75: 25$ & $53.1 \pm 0.3 \mathrm{~b}$ & $90.6 \pm 0.2 \mathrm{~b}$ & $28.5 \pm 0.3 \mathrm{~d}$ & $16.0 \pm 0.2 \mathrm{~b}$ & $\operatorname{tr}$ & $188.2 \pm 0.1 \mathrm{~b}$ \\
$50: 50$ & $52.5 \pm 0.2 \mathrm{C}$ & $44.5 \pm 0.4 \mathrm{~d}$ & $30.0 \pm 0.1 \mathrm{~b}$ & $15.6 \pm 0.1 \mathrm{C}$ & $\operatorname{tr}$ & $142.7 \pm 0.6 \mathrm{~d}$ \\
$25: 75$ & $56.3 \pm 0.1 \mathrm{a}$ & $45 \pm 1 \mathrm{~d}$ & $19.4 \pm 0.2 \mathrm{f}$ & $15.1 \pm 0.1 \mathrm{~d}$ & $\operatorname{tr}$ & $136 \pm 1 \mathrm{f}$ \\
$0: 100$ & $48.0 \pm 0.1 \mathrm{~d}$ & $72 \pm 1 \mathrm{C}$ & $20.5 \pm 0.4 \mathrm{e}$ & $12.6 \pm 0.1 \mathrm{f}$ & $\operatorname{tr}$ & $153 \pm 1 \mathrm{c}$ \\
Urea & $52.3 \pm 0.2 \mathrm{C}$ & $43 \pm 1 \mathrm{e}$ & $29.5 \pm 0.6 \mathrm{C}$ & $13.6 \pm 0.1 \mathrm{e}$ & $\operatorname{tr}$ & $138.0 \pm 0.7 \mathrm{e}$ \\
\hline
\end{tabular}

In each column, different lowercase letters indicate significant differences between samples according to Tukey's test $(P=0.05)$.

Table 4. Composition in tocopherols $\left(\mathrm{mg} \mathrm{kg}^{-1} \mathrm{dw}\right.$ ) of Cichorium spinosum leaves in relation to the form of nitrogen in the nutrient solution (mean \pm SD)

\begin{tabular}{lccc}
$\mathrm{NO}_{3}{ }^{-}: \mathrm{NH}_{4}{ }^{+}$ & $\alpha$-Tocopherol & $\delta$-Tocopherol & Total tocopherols \\
\hline $100: 0$ & $20.9 \pm 0.1 \mathrm{a}$ & $26.0 \pm 0.2 \mathrm{a}$ & $46.9 \pm 0.1 \mathrm{a}$ \\
$75: 25$ & $11.9 \pm 0.1 \mathrm{f}$ & $17.8 \pm 0.9 \mathrm{c}$ & $30 \pm 1 \mathrm{~d}$ \\
$50: 50$ & $20.5 \pm 0.4 \mathrm{~b}$ & $14.1 \pm 0.1 \mathrm{~d}$ & $35 \pm 1 \mathrm{c}$ \\
$25: 75$ & $18.3 \pm 0.1 \mathrm{c}$ & $18.5 \pm 0.1 \mathrm{~b}$ & $36.8 \pm 0.1 \mathrm{~b}$ \\
$0: 100$ & $17.4 \pm 0.1 \mathrm{~d}$ & $17.8 \pm 0.5 \mathrm{c}$ & $35 \pm 1 \mathrm{c}$ \\
Urea & $17.0 \pm 0.2 \mathrm{e}$ & $12.8 \pm 0.5 \mathrm{e}$ & $29.8 \pm 0.6 \mathrm{~d}$ \\
\hline
\end{tabular}

In each column, different lowercase letters indicate significant differences between samples according to Tukey's test $(P=0.05)$.

$\mathrm{NH}_{4}-\mathrm{N}\left(50: 50 \mathrm{NO}_{3}-\mathrm{N}: \mathrm{NH}_{4}-\mathrm{N}\right)$ caused a significant increase in the SFA fraction. The percentage of MUFA remained stable in plants fertigated with nutrient solutions containing from $50 \%$ to $100 \%$ of $\mathrm{NO}_{3}-\mathrm{N}$ and decreased when $100 \%$ ureic nitrogen or a higher proportion of $\mathrm{NH}_{4}-\mathrm{N}$ was used. Instead, the exclusive use of $\mathrm{NH}_{4}-\mathrm{N}$ caused an increase in eicosatrienoic acid (C20:3n3) and especially of $\alpha$-linolenic acid (C18:3n3), thereby determining an increase in the percentage of PUFA and a higher PUFA/SFA ratio, suggesting that $100 \% \mathrm{NH}_{4}-\mathrm{N}$ fertigating solutions may be used to fortify the nutritional value of $C$. spinosum by increasing the concentration of omega- 3 fatty acids and the PUFA/SFA ratio. The lowest percentage of $\alpha$-linolenic acid (C18:3n3) and PUFA were observed in plants grown with a $50: 50 \mathrm{NO}_{3}-\mathrm{N} \mathrm{NH}_{4}-\mathrm{N}$ ratio, followed by those receiving $100 \%$ ureic nitrogen. The leaves of plants fertigated with a $25: 75 \mathrm{NO}_{3}-\mathrm{N}: \mathrm{NH}_{4}-\mathrm{N}$ ratio were characterized by the highest omega-6/omega-3 fatty acids ratio as a result of a higher concentration of both linoleic (C18:2n6c) and $\gamma$-linolenic (C18:3n6) acid.

\section{Effect of the $\mathrm{NO}_{3}-\mathrm{N}: \mathrm{NH}_{4}-\mathrm{N}$ on phenolic compounds}

The chromatographic characteristics of the tentatively identified compounds and the quantification results of C.spinosum leaves are presented in Table 6. Compounds were identified based on their retention time, UV-visible and mass spectra characteristics. Thirteen compounds were identified in total, including four phenolic acids (hydroxycinnamic acid derivatives) and nine flavonoid glycoside derivatives, of which eight were flavonols (mainly quercetin, kaempferol and isorhamnetin derivatives) and one was flavone (apigenin derivative). All the identified compounds have been previously identified in C. spinosum. 5,6,37,39

The nutrient solution $\mathrm{NO}_{3}-\mathrm{N} \mathrm{NH}_{4}-\mathrm{N}$ ratio had a significant impact on the phenolic profile of $C$. spinosum leaves (Table 6). The main phenolic compounds detected were chicoric acid (on average,
53\% cis- and 47\% trans-chicoric acid) and 5-O-caffeoylquinic acid among the phenolic acids, and kaempferol-O-glucuronide, quercetin-3-O-glucuronide and kaempferol-3-O-glucuronide among the flavonoid compounds. These results are consistent with that reported in previous studies on C. spinosum, except for the lower proportion of total flavonoids (TF) compared to total phenolic acids (TPA). ${ }^{6,39}$ TPA ranged between $31.9 \%$ and $46.9 \%$ of the TPC, and TF ranged between $53.1 \%$ and $68.1 \%$ of the total phenolic compounds (TPC), whereas a higher percentage of TPA was observed by Petropoulos et al. ${ }^{6,37}$ The highest content of TPA, TF and TPC was observed in plants supplied with a 75:25 $\mathrm{NO}_{3}-\mathrm{N}: \mathrm{NH}_{4}-\mathrm{N}$ ratio fertigating solution. Compared to plants fertigated with $100 \%$ ureic nitrogen, the high value of TPA observed with the $75: 25 \mathrm{NO}_{3}-\mathrm{N}: \mathrm{NH}_{4}-\mathrm{N}$ ratio was primarily the result of an increase in cis chicoric acid and 5-O-caffeoylquinic acid, whereas the higher TF was mainly a consequence of the increase in quercetin-3-O-glucuronide and kaempferol-O-glucuronide.

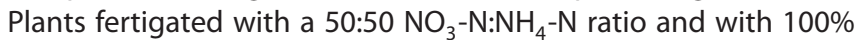
$\mathrm{NO}_{3}-\mathrm{N}$ had the second highest content of TPA and TF, respectively. The lowest TPA, TF and TPC values were observed in plants fertigated with a $25: 75 \mathrm{NO}_{3}-\mathrm{N}: \mathrm{NH}_{4}-\mathrm{N}$ ratio solution, followed by plants fertilized with $100 \%$ urea.

Several studies have shown that the biosynthesis of phenolic compounds is highly influenced by $\mathrm{N}$ fertilization practices and, in general, a lower availability of $\mathrm{N}$ is associated with an increase in phenolic compounds. ${ }^{40,41}$ Instead, there is limited and contrasting evidence available with respect to how the biosynthesis of phenolic compounds is affected by the form of $\mathrm{N}$. In a study conducted on onion, Mollavali et al. ${ }^{42}$ observed an increased concentration of quercetin-3, $4^{\prime}$-di-O- $\beta$-D-glucoside and quercetin- $4^{\prime}-O-\beta$-D-glucoside in plants grown with additional predominant $\mathrm{NH}_{4}-\mathrm{N}$. The increased flavonol concentration observed was also associated with a higher phenylalanine ammonia lyase (PAL) in plants grown predominantly with $\mathrm{NH}_{4}-\mathrm{N}$. Such results were consistent with the findings obtained in other studies demonstrating that the enzyme PAL along with the glutamine synthase plays a key role in the assimilation and recycling of $\mathrm{NH}_{4}{ }^{+}$, contributing to its detoxification in plant tissues. ${ }^{43,44}$ The role that $\mathrm{NH}_{4}{ }^{+}$may play in triggering a stress response stimulating the biosynthesis of phenolic compounds was also demonstrated by the higher expression of superoxide dismutase and soluble peroxidase enzymes activated in presence of oxidative stress. ${ }^{45}$ The higher TPC observed in the present study with the supply of nutrient solutions with 75:25, 50:50 and 0:100 $\mathrm{NO}_{3}-\mathrm{N}: \mathrm{NH}_{4}-\mathrm{N}$ ratios compared to the exclusive supply of $\mathrm{NO}_{3}-\mathrm{N}$ is consistent with previous studies. An increase in TPC content with increasing the proportion of $\mathrm{NH}_{4}-\mathrm{N}$ in nutrient solution up to $50 \%$ was observed also by Chatzigianni et al. ${ }^{30}$ and Petropoulos et al. ${ }^{6}$ However, the lower content of TPC observed using a $25: 75 \mathrm{NO}_{3}-\mathrm{N}: \mathrm{NH}_{4}-\mathrm{N}$ ratio and $100 \%$ ureic nitrogen suggests 
Table 5. . . Fatty acids composition (\%) of Cichorium spinosum leaves in relation to nutrient solution (NS) composition (mean \pm SD)

\begin{tabular}{|c|c|c|c|c|c|c|}
\hline & \multicolumn{5}{|c|}{$\mathrm{NO}_{3}{ }^{-}: \mathrm{NH}_{4}{ }^{+}$} & \multirow[b]{2}{*}{ Urea } \\
\hline & $100: 0$ & $75: 25$ & $50: 50$ & $25: 75$ & $0: 100$ & \\
\hline $\mathrm{C} 6: 0$ & $0.058 \pm 0.002 b$ & $0.058 \pm 0.002 b$ & $0.065 \pm 0.004 a$ & $0.047 \pm 0.001 c$ & $0.035 \pm 0.003 d$ & $0.065 \pm 0.005 a$ \\
\hline $\mathrm{C} 8: 0$ & $0.012 \pm 0.001 c$ & $0.021 \pm 0.001 \mathrm{a}$ & $0.021 \pm 0.001 a$ & $0.012 \pm 0.001 c$ & $0.012 \pm 0.001 c$ & $0.019 \pm 0.001 b$ \\
\hline $\mathrm{C} 10: 0$ & $0.021 \pm 0.001 \mathrm{a}$ & $0.020 \pm 0.001 a$ & $0.021 \pm 0.001 a$ & $0.015 \pm 0.001 \mathrm{~b}$ & $0.012 \pm 0.001 c$ & $0.017 \pm 0.001 b$ \\
\hline C11:0 & $0.101 \pm 0.001 c$ & $0.126 \pm 0.004 a$ & $0.13 \pm 0.01 \mathrm{a}$ & $0.098 \pm 0.001 c$ & $0.102 \pm 0.002 c$ & $0.118 \pm 0.003 b$ \\
\hline $\mathrm{C} 12: 0$ & $0.031 \pm 0.001 \mathrm{~b}$ & $0.031 \pm 0.001 b$ & $0.033 \pm 0.001 a b$ & $0.023 \pm 0.001 c$ & $0.020 \pm 0.001 c$ & $0.035 \pm 0.001 a$ \\
\hline C14:0 & $0.329 \pm 0.003 c$ & $0.40 \pm 0.02 a$ & $0.433 \pm 0.001 \mathrm{a}$ & $0.298 \pm 0.001 \mathrm{~d}$ & $0.30 \pm 0.02 d$ & $0.382 \pm 0.008 b$ \\
\hline C15:0 & $0.114 \pm 0.001 \mathrm{a}$ & $0.109 \pm 0.001 b$ & $0.117 \pm 0.001 \mathrm{a}$ & $0.105 \pm 0.001 \mathrm{~b}$ & $0.096 \pm 0.003 c$ & $0.114 \pm 0.001 \mathrm{a}$ \\
\hline C16:0 & $9.42 \pm 0.03 d$ & $9.99 \pm 0.03 c$ & $10.60 \pm 0.03 a$ & $8.97 \pm 0.03 f$ & $9.08 \pm 0.01 \mathrm{e}$ & $10.08 \pm 0.08 b$ \\
\hline C16:1 & $1.92 \pm 0.01 b$ & $1.86 \pm 0.04 c$ & $2.07 \pm 0.01 \mathrm{a}$ & $1.87 \pm 0.01 c$ & $1.77 \pm 0.01 \mathrm{~d}$ & $2.07 \pm 0.01 \mathrm{a}$ \\
\hline $\mathrm{C} 17: 0$ & $0.130 \pm 0.004 b$ & $0.123 \pm 0.004 c$ & $0.176 \pm 0.005 a$ & $0.132 \pm 0.006 b$ & $0.114 \pm 0.001 \mathrm{~d}$ & $0.170 \pm 0.002 \mathrm{a}$ \\
\hline C18:0 & $0.711 \pm 0.001 c$ & $0.89 \pm 0.05 a$ & $0.819 \pm 0.003 b$ & $0.617 \pm 0.006 d$ & $0.70 \pm 0.04 c$ & $0.83 \pm 0.03 b$ \\
\hline $\mathrm{C} 18: 1 \mathrm{n} 9 \mathrm{c}$ & $0.691 \pm 0.009 b$ & $0.80 \pm 0.05 a$ & $0.577 \pm 0.004 c$ & $0.459 \pm 0.001 \mathrm{e}$ & $0.47 \pm 0.04 \mathrm{e}$ & $0.50 \pm 0.05 d$ \\
\hline $\mathrm{C} 18: 2 \mathrm{n} 6 \mathrm{c}$ & $16.35 \pm 0.01 b$ & $16.89 \pm 0.01 \mathrm{a}$ & $16.53 \pm 0.01 c$ & $15.08 \pm 0.01 \mathrm{e}$ & $14.9 \pm 0.2 f$ & $15.6 \pm 0.1 \mathrm{~d}$ \\
\hline C18:3n6 & $0.060 \pm 0.001 c$ & $0.086 \pm 0.001 \mathrm{a}$ & $0.077 \pm 0.005 b$ & $0.058 \pm 0.001 c$ & $0.054 \pm 0.001 \mathrm{~d}$ & $0.051 \pm 0.004 d$ \\
\hline C18:3n3 & $68.14 \pm 0.02 c$ & $66.59 \pm 0.04 \mathrm{e}$ & $66.46 \pm 0.04 \mathrm{e}$ & $70.10 \pm 0.08 b$ & $70.6 \pm 0.3 a$ & $67.6 \pm 0.4 d$ \\
\hline $\mathrm{C} 20: 0$ & $0.160 \pm 0.006 d$ & $0.171 \pm 0.001 c$ & $0.20 \pm 0.02 a$ & $0.149 \pm 0.005 \mathrm{e}$ & $0.145 \pm 0.002 \mathrm{e}$ & $0.189 \pm 0.004 b$ \\
\hline C20:1 & $0.038 \pm 0.002 a$ & $0.038 \pm 0.001 a$ & $0.030 \pm 0.001 b$ & $0.032 \pm 0.001 b$ & $0.029 \pm 0.001 b$ & $0.031 \pm 0.001 b$ \\
\hline$C 20: 2$ & $0.087 \pm 0.002 \mathrm{a}$ & $0.069 \pm 0.001 b c$ & $0.067 \pm 0.006 c$ & $0.072 \pm 0.003 b$ & $0.056 \pm 0.002 \mathrm{~d}$ & $0.067 \pm 0.00 c$ \\
\hline C21:0 & $0.041 \pm 0.001 c$ & $0.047 \pm 0.002 b$ & $0.048 \pm 0.001 \mathrm{a}$ & $0.042 \pm 0.003 c$ & $0.028 \pm 0.002 \mathrm{e}$ & $0.034 \pm 0.003 d$ \\
\hline$C 20: 3 n 3$ & $0.206 \pm 0.006 a$ & $0.188 \pm 0.005 b c$ & $0.178 \pm 0.006 c$ & $0.196 \pm 0.009 b$ & $0.21 \pm 0.02 \mathrm{a}$ & $0.22 \pm 0.01 \mathrm{a}$ \\
\hline C22:0 & $0.286 \pm 0.008 d$ & $0.30 \pm 0.01 d$ & $0.34 \pm 0.02 c$ & $0.57 \pm 0.05 a$ & $0.29 \pm 0.0 \mathrm{~d}$ & $0.413 \pm 0.002 b$ \\
\hline C22:1 & $0.033 \pm 0.001 b$ & $0.033 \pm 0.001 b$ & $0.037 \pm 0.003 a$ & $0.024 \pm 0.001 c$ & $0.027 \pm 0.001 c$ & $0.030 \pm 0.001 b$ \\
\hline C23:0 & $0.297 \pm 0.004 c$ & $0.29 \pm 0.02 c$ & $0.32 \pm 0.02 b$ & $0.308 \pm 0.009 b c$ & $0.33 \pm 0.01 b$ & $0.63 \pm 0.06 a$ \\
\hline C24:0 & $0.78 \pm 0.02 b$ & $0.89 \pm 0.04 a$ & $0.66 \pm 0.03 d$ & $0.73 \pm 0.02 c$ & $0.65 \pm 0.02 d$ & $0.69 \pm 0.06 d$ \\
\hline SFA & $12.49 \pm 0.03 d$ & $13.46 \pm 0.03 c$ & $13.97 \pm 0.03 a$ & $12.12 \pm 0.08 \mathrm{e}$ & $11.91 \pm 0.02 f$ & $13.8 \pm 0.2 b$ \\
\hline MUFA & $2.68 \pm 0.01 \mathrm{a}$ & $2.72 \pm 0.01 \mathrm{a}$ & $2.71 \pm 0.01 \mathrm{a}$ & $2.38 \pm 0.01 c$ & $2.30 \pm 0.04 d$ & $2.63 \pm 0.03 b$ \\
\hline PUFA & $84.83 \pm 0.03 c$ & $83.82 \pm 0.04 d$ & $83.31 \pm 0.04 \mathrm{e}$ & $85.50 \pm 0.09 b$ & $85.79 \pm 0.01 \mathrm{a}$ & $83.6 \pm 0.3 d$ \\
\hline PUFA/SFA & $6.79 \pm 0.03 c$ & $6.23 \pm 0.04 d$ & $6.00 \pm 0.03 \mathrm{e}$ & $7.05 \pm 0.08 b$ & $7.20 \pm 0.03 a$ & $6.06 \pm 0.03 \mathrm{e}$ \\
\hline $\mathrm{n} 6 / \mathrm{n} 3$ & $0.240 \pm 0.002 c$ & $0.254 \pm 0.005 a$ & $0.249 \pm 0.003 b$ & $0.215 \pm 0.007 \mathrm{e}$ & $0.211 \pm 0.003 \mathrm{e}$ & $0.231 \pm 0.008 d$ \\
\hline \multicolumn{7}{|c|}{$\begin{array}{l}\text { Caproic acid (C6:0); caprylic acid (C8:0); capric acid (C10:0); undecylic acid (C11:0); lauric acid (C12:0); myristic acid (C14:0); pentadecylic acid } \\
\text { (C15:0); palmitic acid (C16:0); palmitoleic acid (C16:1); margaric acid (C17:0); stearic acid (C18:0); oleic acid (C18:1n9c); linoleic acid (C18:2n6c); } \\
\gamma \text {-linolenic acid (C18:3n6); } \alpha \text {-linolenic acid (C18:3n3); arachidic acid (C20:0); paulinic acid (C20:1); dihomo-linoleic acid (C20:2); heneicosylic acid (C21:0); } \\
\text { eicosatrienoic acid (C20:3n3); behenic acid (C22:0); erucic acid (C22:1); tricosylic acid (C23:0); lignoceric acid (C24:0); SFA: saturated fatty acids; MUFA: } \\
\text { monounsaturated fatty acids; PUFA: polyunsaturated fatty acids; } n 6 / n 3: \text { omega-6/omega-3 fatty acids. } \\
\text { In each row, different lowercase letters indicate significant differences between samples according to Tukey's test }(P=0.05) \text {. }\end{array}$} \\
\hline
\end{tabular}

that other factors may be involved in modulating the biosynthesis of phenols and that a source of stress or a toxic effect such as that likely caused when using ureic nitrogen may not determine an increase in phenolic compounds.

Effect of the $\mathrm{NO}_{3}-\mathrm{N}: \mathrm{NH}_{4}-\mathrm{N}$ on cytotoxic and antitumor activity The $\mathrm{N}$ composition of the nutrient solution had no effect on the cytotoxicity of C. spinosum leaves (data not shown). Expressed as the sample concentration responsible for $50 \%$ inhibition of growth $\left(\mathrm{GI}_{50} \mu \mathrm{g} \mathrm{mL}^{-1}\right)$ in primary culture of selected non-tumor (PLP2, HeLa) and tumor (HepG2, MCF-7, NCl-H460) cell lines, the C. spinosum leaf cytotoxicity was more than $400 \mu \mathrm{g} \mathrm{mL}^{-1}$, regardless of the composition of the nutrient solution.

\section{PCA}

The results of the PCA are presented in Fig. 1 and allow a clear distinction of the effects of nitrogen form on yield, DM and the nutritional profile of C. spinosum leaves. The first two principal components (PCs) accounted for $67.6 \%$ of the total variance, attributing $44.6 \%$ to $\mathrm{PC} 1$ and $23.1 \%$ to $\mathrm{PC2}$. Most of the nutritional variables examined were positively correlated with $\mathrm{PC} 1$, and only a few parameters were negatively correlated with PC1. The variables with the highest positive correlation coefficient were phenolic compounds, including kaempferol-3-O-(6'-O-acetyl)-glucoside (0.97), quercetin-3-O-glucuronide (0.97), kaempferol-3-O-glucuronide (0.92), kaempferol-O-glucuronide (0.90), isorhamnetin-3-Oglucuronide (0.90), apigenin-7-O-glucuronide (0.90), quercetin-7-O-(6'-O-acetyl)-glucoside (0.84) and isorhamnetin3-O-(6"-O-acetyl)-glucoside (0.75) among the flavonoids, as well as cis chicoric acid (0.95) and caftaric acid (0.87) among the phenolic acids. A high positive correlation with PC1 was observed also for linoleic acid $(C 18: 2 n 6 c, 0.83)$ and for the total organic acids (0.69). The PC1 was negatively correlated with $C$. spinosum leaf DM (-0.74) and linolenic acid (C18:3n3) (-0.69) content. The PC1 allowed a clear separation of plants grown with a higher proportion of $\mathrm{NO}_{3}-\mathrm{N}(100: 0 ; 75: 25)$ or with a 50:50 $\mathrm{NO}_{3}-\mathrm{N}: \mathrm{NH}_{4}-\mathrm{N}$ ratio from those grown with prevalent $\mathrm{NH}_{4}-\mathrm{N}(0: 100 ; 25: 75)$ or with $100 \%$ ureic nitrogen placed, respectively, on the right and 


\begin{tabular}{|c|c|c|c|c|c|c|c|c|c|c|c|c|c|c|c|c|c|}
\hline 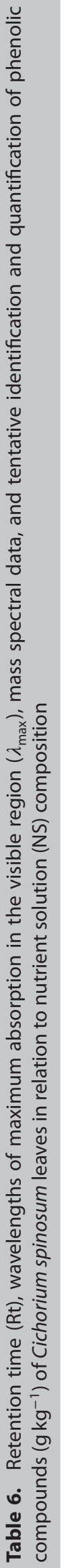 & $\begin{array}{l}\sum_{i}^{+} \\
O_{i}^{+} \\
O^{m}\end{array}$ & 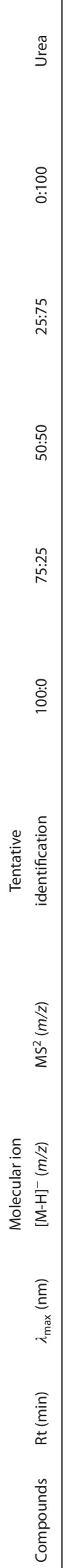 & 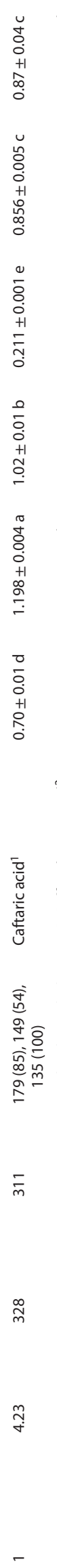 & 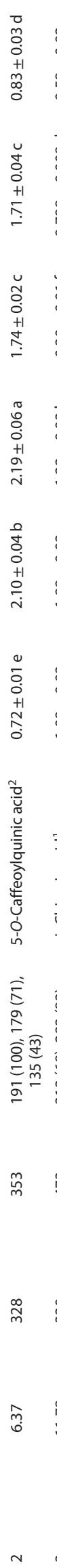 & 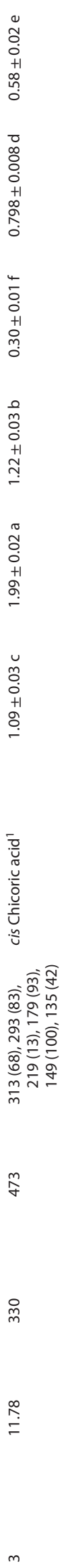 & 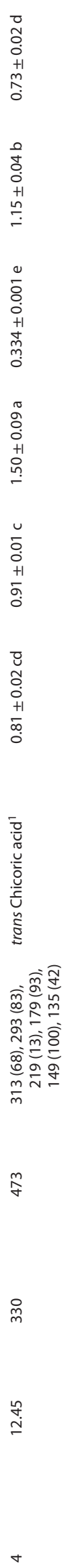 & $\begin{array}{l}0 \\
0 \\
0 \\
0 \\
+1 \\
0 \\
0 \\
0 \\
0 \\
0 \\
0 \\
0 \\
0 \\
0 \\
+1 \\
0 \\
0 \\
0 \\
0 \\
\\
0 \\
0 \\
0 \\
+1 \\
+1 \\
0 \\
0\end{array}$ & 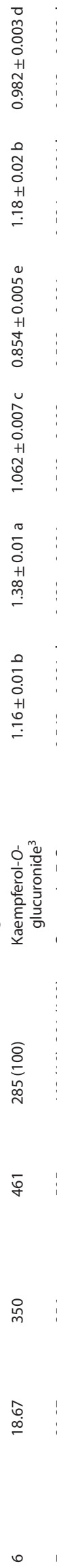 & 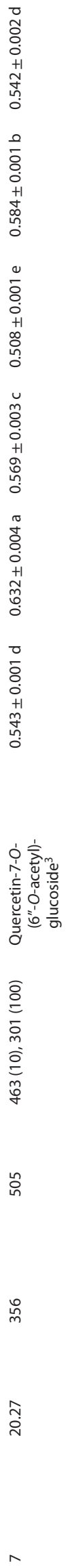 & 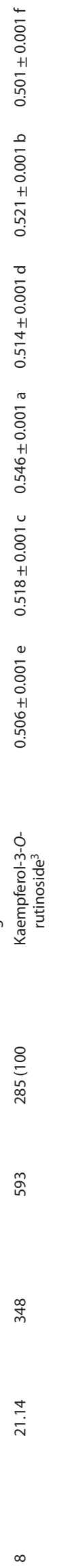 & 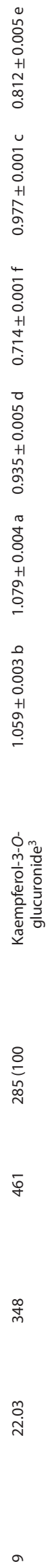 & 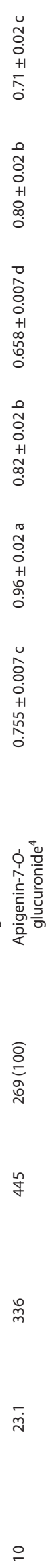 & 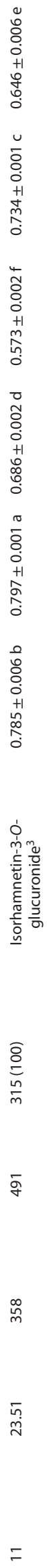 & 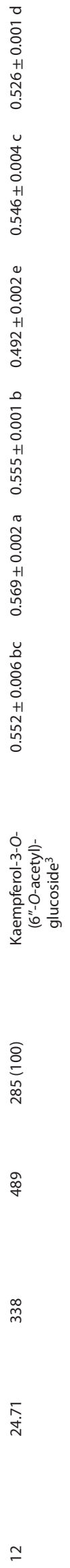 & 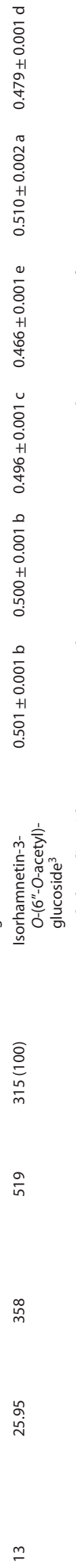 & 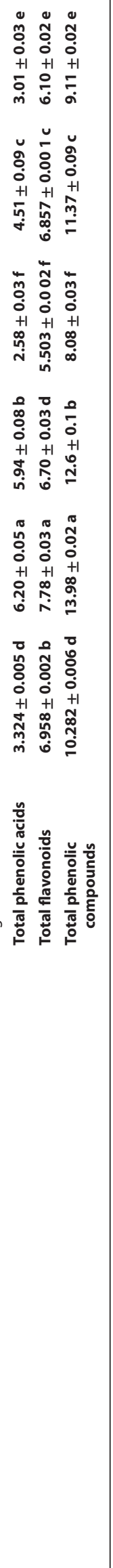 & 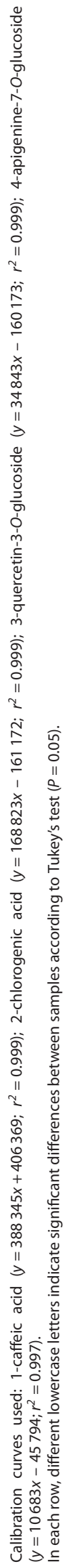 \\
\hline
\end{tabular}




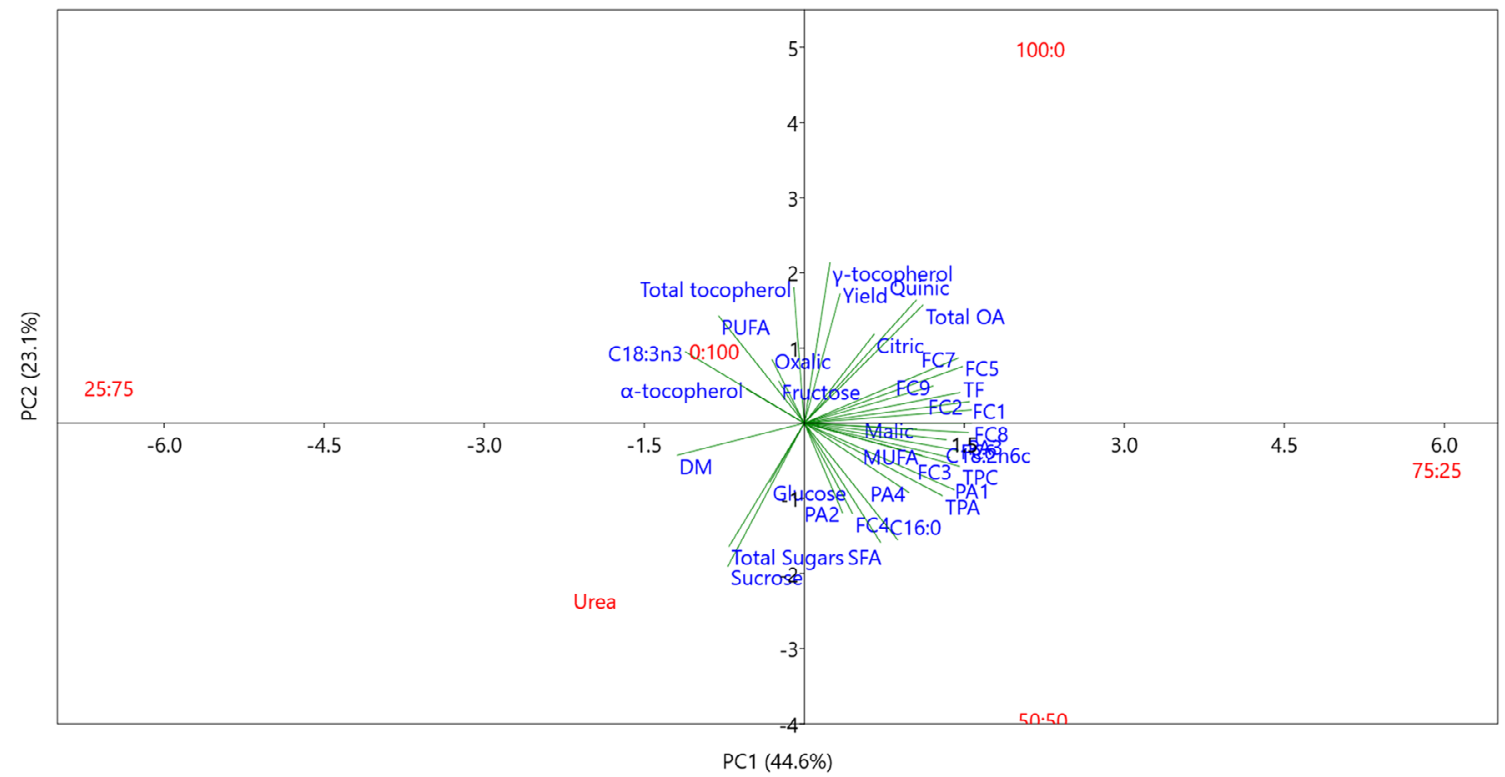

Figure 1. Principal component analysis biplot (PC1 versus PC2) showing the spatial distribution of the nutritional parameters, yield and dry matter content (DM) of leaves of $C$. spinosum fertigated with nutrient solutions characterized by different $\mathrm{NO}_{3}-\mathrm{N}^{\mathrm{N}} \mathrm{NH}_{4}-\mathrm{N}$ ratios $(100: 0,75: 25,50: 50,25: 75$, $0: 100)$ or by urea as the sole source on nitrogen. Parameters considered include: yield and DM previously reported by Kolovou et al. ${ }^{24}$; oxalic, quinic, malic, citric acid and total organic acids (Total OA) fructose, glucose, sucrose and total sugars, $\alpha$-tocopherol, $\gamma$-tocopherol, total tocopherol caftaric acid (PA1), 5-O-caffeoylquinic acid (PA2), cis chicoric acid (PA3), trans chicoric acid (PA4), quercetin-3-O-glucuronide (FC1), kaempferol-O-glucuronide (FC2), quercetin-7-O-(6'-O-acetyl)-glucoside (FC3), kaempferol-3-O-rutinoside (FC4), kaempferol-3-O-glucuronide (FC5), apigenin-7-O-glucuronide (FC6), isorhamnetin-3-O-glucuronide (FC7), kaempferol-3-O-(6'-O-acetyl)-glucoside (FC8), isorhamnetin-3-O-(6"-O-acetyl)-glucoside (FC9), total phenolic acids (TPA), total flavonoids (TF) and total phenolic compounds (TPC) palmitic acid (C16:0), linoleic acid (C18:2n6c) linolenic acid (C18:3n), saturated fatty acids (SFA), monounsaturated fatty acids (MUFA) and polyunsaturated fatty acids (PUFA).

left side of $\mathrm{PC} 1$, suggesting that the former, and especially those grown with a $75: 25 \mathrm{NO}_{3}-\mathrm{N}: \mathrm{NH}_{4}-\mathrm{N}$ ratio, were characterized by a higher TPC and linoleic acid (C18:2n6c) (Tables 5 and 6). The latter were characterized by a relatively lower TPC (Table 6), lower oxalic acid (Table 3) and higher linolenic acid (C18:3n3) content, especially in the case of plants grown with a 0:100 $\mathrm{NO}_{3}-\mathrm{N}: \mathrm{NH}_{4}-\mathrm{N}$ ratio (Table 5), and a higher DM content, especially in the case of plants grown with a 25:75 $\mathrm{NO}_{3}-\mathrm{N}: \mathrm{NH}_{4}-\mathrm{N}$ ratio. The PC2 was positively correlated with $\gamma$-tocopherol (0.95), total tocopherols $(0.81)$, yield $(0.77)$, quinic acid $(0.73)$ and total organic acids (0.70), as well as negatively correlated with the content of total sugars $(-0.73)$ and especially sucrose $(-0.85)$, and also with SFA $(-0.71)$. The PC2 clearly separated plants grown exclusively with $\mathrm{NO}_{3}-\mathrm{N}$ characterized by a higher yield, total organic acids (Table 3 ) and total tocopherols content (Table 4) from those grown with a $50: 50 \mathrm{NO}_{3}-\mathrm{N}: \mathrm{NH}_{4}-\mathrm{N}$ ratio and with urea characterized by a higher sucrose (Table 2) and SFA content (Table 5).

\section{CONCLUSIONS}

Analyzing the variation of the nutritional profile of $C$. spinosum in response to fertigation testing the full range of $\mathrm{NO}_{3}-\mathrm{N}: \mathrm{NH}_{4}-\mathrm{N}$ $(100: 0,75: 25,50: 50,25: 75,0: 100)$ and $100 \%$ ureic- $N$, the present study revealed that the form of $\mathrm{N}$ provided via fertigation has a considerable impact on the content of both nutritional and anti-nutritional compounds. Tocopherols ( $\alpha$ - and $\delta$-tocopherol) and organic acids (quinic, malic, citric and oxalic acid) content were maximized in plants grown exclusively with $\mathrm{NO}_{3}-\mathrm{N}$ (100:0). Fertigation with a 75:25 $\mathrm{NO}_{3}-\mathrm{N}_{\mathrm{NH}_{4}}-\mathrm{N}$ ratio allowed maximization of the content of phenolic compounds, including both flavonoids and phenolic acids, as well as the concentration of linoleic acid (C18:2n6c), although the main phenolic compound content (5-O-caffeoylquinic and chicoric acid) was the highest for the solution with a balanced ratio of $\mathrm{NO}_{3}{ }^{-}$and $\mathrm{NH}_{4}{ }^{+}$nitrogen $\left(50: 50 \mathrm{NO}_{3}{ }^{-}: \mathrm{NH}_{4}-\mathrm{N}\right)$. On the other hand, the exclusive use of $\mathrm{NH}_{4}-\mathrm{N}(0: 100)$ ensured the highest content of linolenic acid (C18:3n3) and polyunsaturated fatty acids and, at the same time, the lowest content of oxalic acid, which is considered to be an antinutrient. The exclusive use of ureic- $\mathrm{N}$ was toxic for plants of C. spinosum and did not enhance its nutritional profile. When examining the impact of the form of $\mathrm{N}$ on the cytotoxicity effect of $C$. spinosum leaf extracts against non-tumor (PLP2, HeLa) and tumor (HepG2, MCF-7, NCl-H460) cell lines, no significant effects were observed for all of the $\mathrm{N}$ treatments tested. It is concluded that, by modulating the $\mathrm{NO}_{3}-\mathrm{N}: \mathrm{NH}_{4}-\mathrm{N}$ ratio of the nutrient solution supplied to $C$. spinosum, it is possible to enhance the content of desirable health-promoting compounds and reduce the content of antinutrients, thus increasing the overall quality of the final product.

\section{ACKNOWLEDGEMENTS}

We are grateful to the Foundation for Science and Technology (FCT, Portugal) and FEDER under Programme PT2020 for financial support to CIMO (UID/AGR/00690/2019), L. Barros, A. Fernandes and R. C. Calhelha's contract. The authors are grateful to the FEDER-Interreg España-Portugal programme for financial support through the project 0377_lberphenol_6_E.

\section{CONFLICT OF INTERESTS}

The authors declare that they have no conflicts of interest. 


\section{REFERENCES}

1 Pereira C, Barros L, Carvalho AM and Ferreira ICFR, Nutritional composition and bioactive properties of commonly consumed wild greens: potential sources for new trends in modern diets. Food Res Int 44:2634-2640 (2011).

2 Morales P, Ferreira ICFR, Carvalho AM, Sánchez-Mata MC, Cámara M, Fernández-Ruiz $\mathrm{V}$ et al., Mediterranean non-cultivated vegetables as dietary sources of compounds with antioxidant and biological activity. LWT-Food Sci Technol 55:389-396 (2014).

3 Boari F, Cefola M, Di GF, Pace B, Serio F and Cantore V, Effect of cooking methods on antioxidant activity and nitrate content of selected wild Mediterranean plants. Int J Food Sci Nutr 64:870-876 (2013).

4 Simopoulos AP, Omega-3 fatty acids and antioxidants in edible wild plants. Biol Res 37:263-277 (2004).

5 Petropoulos S, Levizou E, Ntatsi G, Fernandes Â, Petrotos K, Akoumianakis K et al., Salinity effect on nutritional value, chemical composition and bioactive compounds content of Cichorium spinosum L. Food Chem 214:129-136 (2017).

6 Petropoulos S, Fernandes Â, Karkanis A, Antoniadis V, Barros L and Ferreira I, Nutrient solution composition and growing season affect yield and chemical composition of Cichorium spinosum plants. Sci Hortic 231:97-107 (2018).

7 Petropoulos S, Fernandes Â, Vasileios A, Ntatsi G, Barros L and Ferreira I, Chemical composition and antioxidant activity of Cichorium spinosum L. leaves in relation to developmental stage. Food Chem 239:946-952 (2018).

8 Petropoulos S, Ntatsi G, Levizou E, Barros L and Ferreira I, Nutritional profile and chemical composition of Cichorium spinosum ecotypes. LWT-Food Sci Technol 73:95-101 (2016).

9 Hord NG, Tang Y and Bryan NS, Food sources of nitrates and nitrites: the physiologic context for potential health benefits. Am J Clin Nutr 90:1 - 10 (2009).

10 Perner H, Schwarz D, Krumbein A and George E, Influence of sulfur supply, ammonium nitrate ratio, and arbuscular mycorrhizal colonization on growth and composition of Chinese chive. Sci Hortic 130:485-490 (2011).

11 Fallovo C, Rouphael Y, Rea E, Battistelli A and Colla G, Nutrient solution concentration and growing season affect yield and quality of Lactuca sativa L. var. acephala in floating raft culture. J Sci Food Agric 89:1682-1689 (2009).

12 Fontana E, Hoeberechts J, Nicola S, Cros V, Palmegiano GB and Peiretti $P G$, Nitrogen concentration and nitrate ammonium ratio affect yield and change the oxalic acid concentration and fatty acid profile of purslane (Portulaca oleracea L.) grown in a soilless culture system. J Sci Food Agric 86:2417-2424 (2006).

13 Rouphael Y, Kyriacou MC, Petropoulos SA, De PS and Colla G, Improving vegetable quality in controlled environments. Sci Hortic 234:275-289 (2018).

14 Palaniswamy UR, McAvoy RJ and Bible B, Oxalic acid concentrations in purslane (Portulaca oleraceae L.) is altered by the stage of harvest and the nitrate to ammonium ratios in hydroponics. Sci Hortic 629:299-305 (2004).

15 Di Gioia F, Renna M and Sprouts SP, Microgreens and "Baby Leaf" Vegetables. Springer, Boston, MA, pp. 403-432 (2017).

16 Kyriacou MC, Rouphael Y, Di Gioia F, Kyratzis A, Serio F, Renna M et al., Micro-scale vegetable production and the rise of microgreens. Trends Food Sci Technol 57:103-115 (2016).

17 Fallovo C, Schreiner M, Schwarz D, Colla G and Krumbein A, Phytochemical changes induced by different nitrogen supply forms and radiation levels in two leafy brassica species. J Agric Food Chem 59:4198-4207 (2011).

18 Dai J and Mumper RJ, Plant phenolics: extraction, analysis and their antioxidant and anticancer properties. Molecules 15:7313-7352 (2010).

19 Prior $\mathrm{RL}$, Fruits and vegetables in the prevention of cellular oxidative damage. Am J Clin Nutr 78:570-578 (2003).

20 Ceccanti C, Landi M, Benvenuti S, Pardossi A and Guidi L, Mediterranean wild edible plants: weeds or "new functional crops"? Molecules 23:2299 (2018).

21 Szalai G, Dai N, Danin A, Dudai N and Barazani O, Effect of nitrogen source in the fertilizing solution on nutritional quality of three members of the Portulaca oleracea aggregate. J Sci Food Agric 90:2039-2045 (2010).

22 De Cortes Sánchez-Mata M and Tardío J, Mediterranean Wild Edible Plants. Springer, New York, NY (2011).
23 Brieudes V, Angelis A, Vougogiannopoulou K, Pratsinis H, Kletsas D, Mitakou $S$ et al., Phytochemical analysis and antioxidant potential of the phytonutrient-rich decoction of Cichorium spinosum and $C$. intybus. Planta Med 82:1070-1078 (2016).

24 Kolovou P, Antoniadis V, Karkanis A, Ferreira I, and Petropoulos S. The effect of nutrient solution composition on development of Cichorium spinosum plants, in Proceedings of the VIII International Scientific Agriculture Symposium 'Agrosym 2017', Jahorina, Bosnia and Herzegovina, pp. 270-274 (2017).

25 Anesti S, Fasoli K, Petropoulos S, Ntatsi G, Antoniadis V, and Ferreira ICFR. Effect of ammonium fertilizer on growth and quality of Cichorium spinosum plants, in VII International Scientific Agriculture Symposium 'Agrosym 2016', Jahorina, Bosnia and Erzegovina, pp. $827-833$ (2016).

26 Barros L, Pereira E, Calhelha RC, Dueñas M, Carvalho AM, Santos-Buelga C etal., Bioactivity and chemical characterization in hydrophilic and lipophilic compounds of Chenopodium ambrosioides L. J Funct Foods 5:1732-1740 (2013).

27 Bessada SMF, Barreira JCM, Barros L, Ferreira ICFR and Oliveira MBPP, Phenolic profile and antioxidant activity of Coleostephus myconis (L.) Rchb.f.: an underexploited and highly disseminated species. Ind Crops Prod 89:45-51 (2016).

28 Abreu RM, Ferreira IC, Calhelha RC, Lima RT, Vasconcelos $M H$, Adega $F$ etal., Anti-hepatocellular carcinoma activity using human HepG2 cells and hepatotoxicity of 6-substituted methyl 3-aminothieno[3,2-b]pyridine-2-carboxylate derivatives: in vitro evaluation, cell cycle analysis and QSAR studies. Eur J Med Chem 46:5800-5806 (2011).

29 Hammer $\varnothing$, Harper DAT and Ryan PD, PAST: paleontological statistics software package for education and data analysis. Palaeontol Electron 4:9 (2001).

30 Chatzigianni M, Alkhaled B, Livieratos I, Stamatakis A, Ntatsi G and Savvas D, Impact of nitrogen source and supply level on growth, yield and nutritional value of two contrasting ecotypes of Cichorium spinosum L. grown hydroponically. J Sci Food Agric 98:1615-1624 (2017).

31 Di Gioia F, Gonnella M, Buono V, Ayala O and Santamaria P, Agronomic, physiological and quality response of romaine and red oak-leaf lettuce to nitrogen input. Ital J Agron 12:47-58 (2017).

32 Di Gioia F, Gonnella M, Buono V, Ayala O, Cacchiarelli J and Santamaria $P$, Calcium cyanamide effects on nitrogen use efficiency, yield, nitrates, and dry matter content of lettuce. Agron J 109:354-362 (2017).

33 Flores P, Carvajal M, Cerdá A and Martínez V, Salinity and ammonium/nitrate interactions on tomato plant development, nutrition, and metabolites. J Plant Nutr 24:1561-1573 (2001).

34 Zhang YPSY, Lin XY, Zhang YPSY, Zheng SJ and Du ST, Effects of nitrogen levels and nitrate/ammonium ratios on oxalate concentrations of different forms in edible parts of spinach. J Plant Nutr 28:2011-2025 (2005).

35 Kirkby EA and Mengel K, lonic balance in different tissues of the tomato plant in relation to nitrate, urea, or ammonium nutrition. Plant Physiol 42:6-14 (1967).

36 Gemede HF and Ratta N, Antinutritional factors in plant foods: potential health benefits and adverse effects. Int J Nutr Food Sci 3:284-289 (2014).

37 Petropoulos S, Fernandes Â, Karkanis A, Ntatsi G, Barros L and Ferreira I, Successive harvesting affects yield, chemical composition and antioxidant activity of Cichorium spinosum L. Food Chem 237:83-90 (2017).

38 Guil JL, Torija ME, Giménez JJ and Rodriguez I, Identification of fatty acids in edible wild plants by gas chromatography. J Chromatogr $A$ 719:229-235 (1996).

39 Petropoulos S, Fernandes A, Barros L and Ferreira I, A comparison of the phenolic profile and antioxidant activity of different Cichorium spinosum L. ecotypes. J Sci Food Agric 98:183-189 (2017).

40 Heimler D, Isolani L, Vignolini P and Romani A, Polyphenol content and antiradical activity of Cichorium intybus L. from biodynamic and conventional farming. Food Chem 114:765-770 (2009).

41 Olsen KM, Lea US, Slimestad R, Verheul M and Lillo C, Differential expression of four Arabidopsis PAL genes; PAL1 and PAL2 have functional specialization in abiotic environmental-triggered flavonoid synthesis. J Plant Physiol 165:1491-1499 (2008). 
42 Mollavali M, Perner H, Rohn S, Hanschen FS and Schwarz D, Nitrogen form and mycorrhizal inoculation amount and timing affect flavonol biosynthesis in onion (Allium cepa L.). Mycorrhiza 28:59-70 (2018).

43 Singh S, Lewis NG and Neil Towers GH, Nitrogen recycling during phenylpropanoid metabolism in sweet potato tubers. J Plant Physiol 153:316-323 (1998).
44 Bernard SM and Habash DZ, The importance of cytosolic glutamine synthetase in nitrogen assimilation and recycling. New Phytol 182:608-620 (2009).

45 Mihaljević S, Radić S, Bauer N, Garić R, Mihaljević B, Horvat G et al., Ammonium-related metabolic changes affect somatic embryogenesis in pumpkin (Cucurbita pepo L.). J Plant Physiol 168:1943-1951 (2011). 